Environment Conservation Journal 19 (3) 59-65, 2018

ISSN 0972-3099 (Print) 2278-5124 (Online)

Abstracted and Indexed

\title{
Present scenario in respect of House-Sparrows' depleting trends and conservation efforts in and around Kurukshetra, Haryana, India
}

\author{
Kaushik Kumar Tirshem $\bowtie$ and Gupta Chand Rohtash
}

Received: 20.05.2018

Revised: 18.07.2018

Accepted: 10.10.2018

\begin{abstract}
The present research work was carried out during 2003 to 2016 to aim the scenario of depleting trends and conservation efforts of House Sparrow in and around Kurukshetra district in Haryana province in India. House Sparrow Passer domesticus was abundantly available in each and every corner of villages, towns and cities in Haryana and Punjab in early 1990s. Today, it has been totally wiped out from its very popular places of abundance. Its depletion is so alarming that now there is no chirping of House sparrow in early Morning and Evening Hours. The extremely low numbers of House Sparrows are directly linked with whooping failure of its broods and also non-availability of nesting places. Infact, latter is very crucial in diminishing common house sparrow populations across the length and breadth of the Indian Subcontinent. Its restoration is impending. The issue is sensitive and gigantic. Conversely, its restorative measures are apparently simple and straight forward. The present studies argued that dwelling houses should necessarily have Verandas and ventilators with shutters inside of walls. Bushes, Bougainvilleas vines, hedges, beri-plants be grown extensively. In addition, wooden boxes of 9x6" be installed on tree branches and within the premises of every human dwelling in all villages, towns, cities and metropolitan cities across Indian- territory to restore house sparrow's alarming depleting populations in modern times. House sparrow responds quickly to rejuvenative measures.
\end{abstract}

Key words: Depleting trends, House Sparrow, Kurukshetra, restorative measures.

\section{Introduction}

House Sparrow is one of the most widespread bird species in the world but its populations have declined markedly in most parts of India (Bhattacharya et al., 2011). House Sparrow belongs to family Passeridae and order Passeriformes. Sexual dimorphism exists. The plumage of females and young birds are pale brown and grey, and males have brighter black, white, and brown markings (Plate-1). Male has boldly coloured head markings, reddish back, and grey underparts (Fig.1, Plate-1). Crown is dark grey from top of its bill to its back and chestnut brown flanking its crown on the sides of its head (Bhattacharya et al., 2010; Brooke, 1973; Daniel, 2008). Male has black around its bill and on its throat and lores. It has a small white stripe between the lores and crown and small white spots immediately behind the eyes with black patches below and above them (Figs.1, 5, Plate-1). Lower plumage is somewhat grey or

\section{Author's Address}

Govt. Senior Secondary School, Hathira, Kurukshetra (136119)

Haryana, India.

E-mail.: drtarshemkaushik@gmail.com white. In male, bill is black in the breeding season and dark grey during the rest of the year (Fig.1, Plate-1). In female plumage, upperparts and head are brown with darker streaks around the mantle. Supercilium is distinctly pale (Ali, 1996). Its underparts are pale grey-brown bill is brownishgrey in female and becomes darker in breeding plumage (Fig.2, Plate-1). The house sparrow was among the first animals to be given a scientific name in biological classification described by Carolous Linnaeus in 1758 in $10^{\text {th }}$ edition of his book "Systema Naturae". There are some 12 subspecies of House Sparrow which were recognized in the Handbook of the Birds of the World. House Sparrows have been studied by Ali and Repley (1987). Whistler (1928) has provided ground zero information on House Sparrows of the Indian Subcontinent. Various naturalists have worked on the various issues relate with house sparrow especially on its Natural history (Felermben, 1997; Ghosh et al., 2010). Very few workers have worked on the depleting populations of house sparrows through 1990s to the present 
times. However, no work has been done on the and fast manner and hence the present endeavour. populations of house sparrow, that too, in a rapid

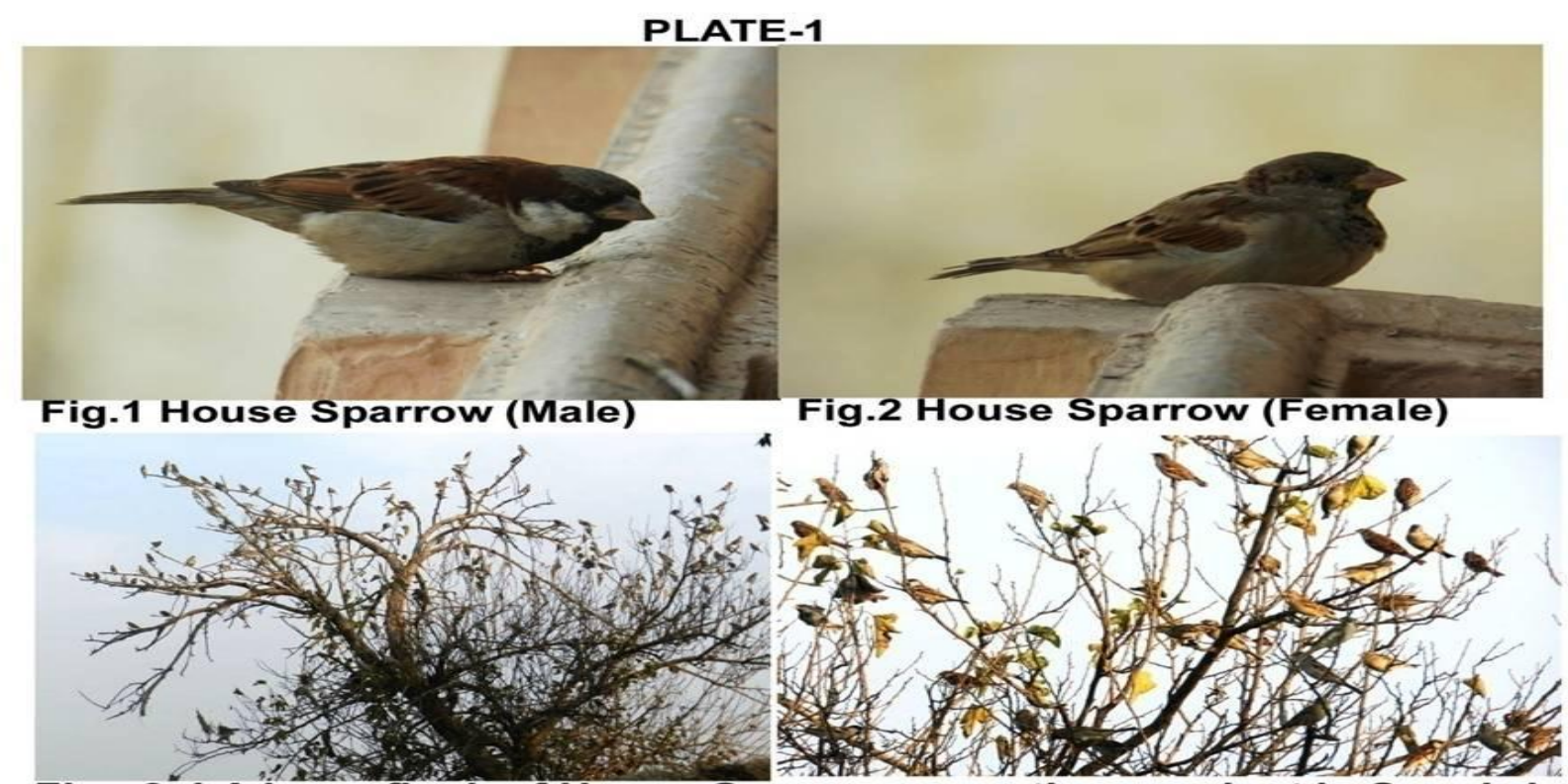

Figs.3-4 A large flock of House Sparrows roosting on plant in Sunehri Khalsa village in Kurukshetra district in Haryana

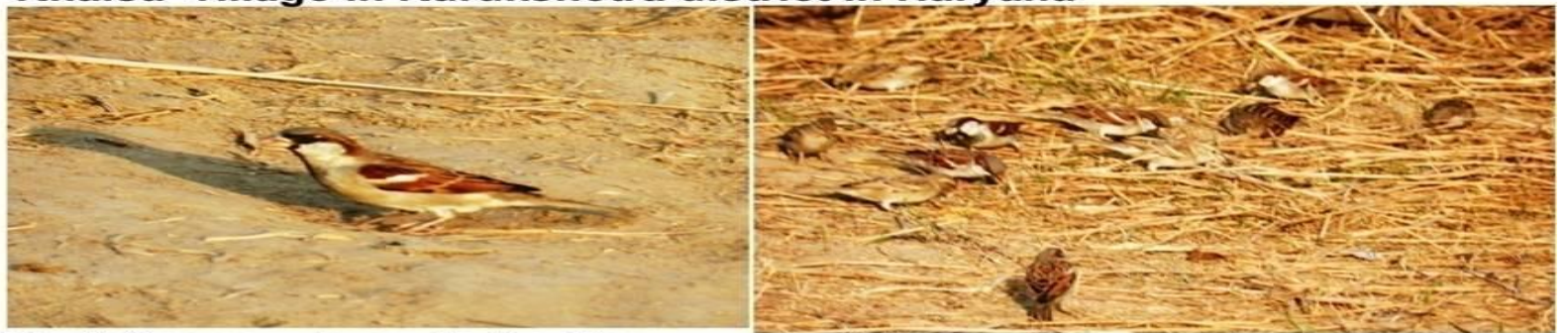

Fig.5 Sparrow busy in feeding

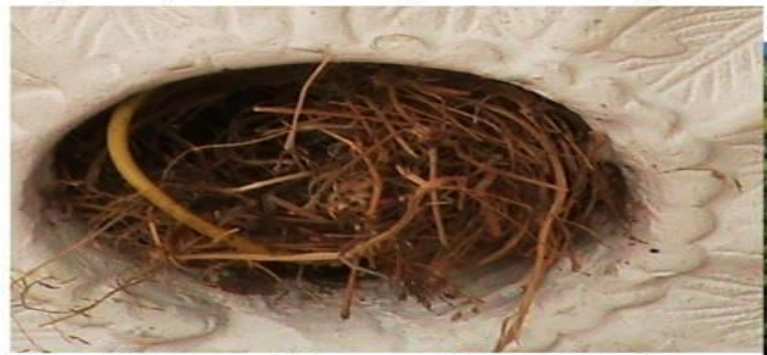

Fig.7 Nest of House Sparrow in Ceiling of ornamental light socket
Fig.6 House Sparrow busy in feeding grains on ground

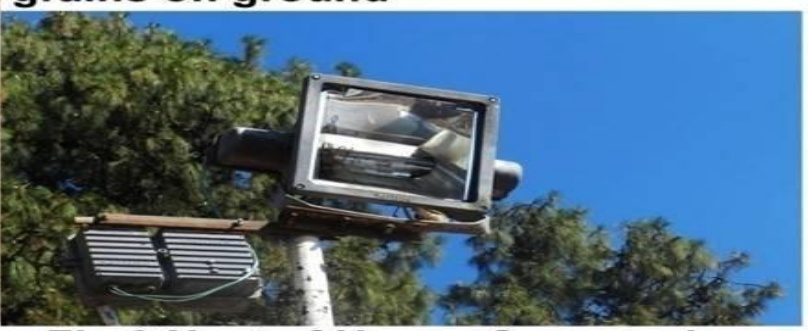

Fig.8 Nest of House Sparrow in the socket of street light

Plate1. Showing different activities of House Sparrow

\section{Materials and Methods}

The material for present studies refers to common house sparrow which no more common now (Fig.12). Instead, it is highly threatened and certainly facing very adverse conditions. The observations span over a period of our 13 years (2003-2016). We have surveyed atleast 500 villages in Haryana but we have focused attention on 50 villages like Sirsama, Shadipur-ladwa, Umri, Jirbari, Samani, Khaspur, Palwal, Amin, Sunehri-Khalsa, Mirzapur, Jyotisar, Lukhi, Jhansa, Bir-mathana, Mathana, Karami, Beholi, Bazidpur, Kanipla, Sarai Sukhi, Morthala- Dudhala, Mukarpur, Kolapur, Bodla, 
Jainpur, Gadli, Ban, Gudha, Budha, Sirsala, Shadipur-Sahidan, Kirmich, Sonti, Haripur, Kharindwa, Khairi, Rampur, Berthala, Lohara, Nivarsi in Kurukshetra district and Raipur-rodan, Samana, Barthal, Bairsal, Bhadson, Barot, Hinori, Labkari, Gari-birbal, Pujam in Karnal district for the observation of nesting and feeding habit of house sparrows in various houses of villagers in these villages. In all 5360 houses spread over 50 villages were visited for the observations of House Sparrow numbers and nesting of house sparrow. We have separated the house into two categories (1) Traditional Houses with mud roof and Verandas and (2) House with cemented roof. Between 2000 and 2014, atleast 500 villages were surveyed. In addition over 100 schools and several universities across the country were surveyed during official visits for one or the other purposes. The surroundings of villages, towns, cities were surveyed to find plantations of beri plants, hedges, bushes and wines of bougainvilleas- exotic decorative plants.

Most of the observations refer to Kurukshetra, Kaithal, Karnal and Faridabad district of Haryana. Extensive survey was done in the vicinity of Kurukshetra district for the observation of chirping of House sparrow. Survey was done as per convenience but preferably at the time of Sunrise, morning, Fore-noon, After-noon, evening time and at the time of sunset. Regular visits were made throughout the study area and attention has been focused on distribution of house Sparrow, nest lodging sites pattern and general activity regimes. Extensive photography was done with the help of cameras Viz. Zenith 1986 model with tele-lens and Nikon Coolpix P500. Earlier, the morning chirping was done by sparrows followed by the doves and Katur-2 of Pigeons in the day times. Today there are no more House- Sparrows and Pigeons are driven away by direct demolishing of their nests etc. Doves have been driven away to faraway places on the outskirts of villages and towns. In these circumstances attention has been focused on the measures to restore house sparrow populations by suggesting effective means.

\section{Results and Discussion}

The house sparrow is a very social bird. It is locally known as "Chidiya and is mostly seen in the vicinity of human habitations. House sparrows are primarily a seedeater and also eat fruits, plant materials and insects. House sparrows preferably like to eat grains in the field and human food scraps (Figs.5, 6, Plate-1). It requires shrubs, vines, dense foliage of trees for roosting [Figs.3, 4, Plate-1]. House sparrow builds their nests in a hole, crevices, human made structure with loose mass of paper, string, grass and weeds lined with hair and feather (Figs.7, 8, Plate-1). The selection of nesting site and nest building is done by male but female may also help. Nesting begins in March and April. House sparrows like to live in large groups (Figs.3, 4 , Plate-1). It is a very vocal bird. They do chirping mostly in the morning and evening times.

It is gregarious and often formed flocks of 10-2050 birds when feeding. Its nests are usually grouped together in clumps. We have observed the scenario of house Sparrows from 2003-2016. In the study period frequency of sighting the House Sparrows is very low. Present studies indicate that House Sparrow was generally seen in two or three birds but never more than 10 birds. At the same time, sighting of nest of house sparrow was also low. It is awesome that in December, 2011, a large flock of about 200 House Sparrows was seen in the outskirt of village Sunehri Khalasa in Kurukshetra district.

House Sparrows were not observed throughout the year but generally seen from July to February. It is crucial to point out that House Sparrow is local migratory bird in Northern India. House Sparrows were frequently seen in rural habitats where food is abundant and conditions are favourable for the formation of nests. House Sparrow is very remarkable bird and also makes nests in the sockets of roof of cemented houses. The house sparrow feeds mostly on the ground, but it flocks in trees and bushes (Plate-1). At feeding stations and nesting sites, female house sparrows are dominant despite their smaller size and in the reproductive period being dominant, they can fight for males. Dust or water bathing is very common in Common House Sparrow and often occurs in groups. House sparrow generally feeds on the seeds of grains and weeds but it is also opportunistic and eats whatever foods are available (Figs.5, 6, Plate-1).

Present studies reveal that House Sparrow was often scavenging for food in garbage containers and congregates in the outdoors of restaurants to feed on leftover food in towns and cities. Its diet also 


\section{Kaushik and Gupta}

Table1. Scenario of House Sparrows prevailing in Haryana province in India from 2003-2016.

\begin{tabular}{|c|c|c|c|c|c|}
\hline $\begin{array}{l}\mathbf{S} \\
\mathbf{N}\end{array}$ & $\begin{array}{l}\text { Name of } \\
\text { Village }\end{array}$ & $\begin{array}{l}\text { Number of } \\
\text { Houses } \\
\text { Searched }\end{array}$ & $\begin{array}{l}\text { No of House } \\
\text { Sparrows } \\
\text { observed }\end{array}$ & $\begin{array}{l}\text { Number of } \\
\text { Nests Seen }\end{array}$ & Remarks \\
\hline 1 & Sirsama & 150 & $20-30$ & $05-07$ & $\begin{array}{l}\text { Nests were only observed in Traditional } \\
\text { Houses where Verandas are available. }\end{array}$ \\
\hline 2 & Shadipur-ladwa & 50 & $10-15$ & $2-3$ & Nests were observed in ceiling of fan. \\
\hline 3 & Umri & 250 & $50-70$ & $5-8$ & $\begin{array}{l}\text { Nests were only observed in Traditional } \\
\text { Houses where Verandas are available. }\end{array}$ \\
\hline 4 & Jirbari & 50 & $12-18$ & NIL & Only cemented Houses were visited. \\
\hline 5 & Samani & 50 & $8-10$ & Nil & Only cemented Houses were visited. \\
\hline 6 & Khaspur & 150 & NIL & NIL & Only cemented Houses were visited. \\
\hline 7 & Palwal & 200 & $60-70$ & $10-14$ & $\begin{array}{l}\text { Only traditional houses with mud roof } \\
\text { were visited. }\end{array}$ \\
\hline 8 & Amin & 150 & $50-70$ & $10-14$ & Only \\
\hline 9 & Sunehri-Khalsa & 50 & $100-150$ & $20-25$ & $\begin{array}{l}\text { Cemented as well as Traditional houses } \\
\text { with Verandas were visited }\end{array}$ \\
\hline 10 & Mirzapur & 50 & NIL & NIL & Only cemented Houses were visited \\
\hline 11 & Jyotisar & 100 & $10-20$ & $02-05$ & Only cemented Houses were visited. \\
\hline 12 & Lukhi & 50 & Nil & Nil & Only cemented Houses were visited. \\
\hline 13 & Jhansa & 100 & $5-10$ & Nil & Only cemented Houses were visited. \\
\hline 14 & Samana & 150 & $20-30$ & $11-15$ & $\begin{array}{l}\text { Traditional house with Verandas were } \\
\text { visited. }\end{array}$ \\
\hline 15 & Raipur-rodan & 200 & $20-25$ & $5-10$ & Only cemented Houses were visited. \\
\hline 16 & Barthal & 250 & $30-40$ & $8-10$ & $\begin{array}{l}\text { Cemented as well as Traditional houses } \\
\text { with Verandas were visited. }\end{array}$ \\
\hline 17 & Birmathana & 150 & $20-25$ & NIL & $\begin{array}{l}\text { Cemented as well as Traditional houses } \\
\text { with Verandas were visited. }\end{array}$ \\
\hline 18 & Mathana & 200 & $10-20$ & $5-10$ & $\begin{array}{l}\text { Cemented as well as Traditional houses } \\
\text { with Verandas were visited. }\end{array}$ \\
\hline 19 & Karami & 100 & $10-20$ & $5-10$ & $\begin{array}{l}\text { Cemented as well as Traditional houses } \\
\text { with Verandas were visited }\end{array}$ \\
\hline 20 & Beholi & 100 & $10-15$ & NIL & $\begin{array}{l}\text { Cemented as well as Traditional houses } \\
\text { with Verandas were visited. }\end{array}$ \\
\hline 21 & Bazidpur & 50 & NIL & NIL & $\begin{array}{l}\text { Cemented as well as Traditional houses } \\
\text { with Verandas were visited. }\end{array}$ \\
\hline 22 & Kanipla & 100 & $5-10$ & NIL & $\begin{array}{l}\text { Cemented as well as Traditional houses } \\
\text { with Verandas were visited }\end{array}$ \\
\hline 23 & Sarai Sukhi & 100 & $10-20$ & $5-8$ & $\begin{array}{l}\text { Cemented as well as Traditional houses } \\
\text { with Verandas were visited. }\end{array}$ \\
\hline 24 & $\begin{array}{l}\text { Morthala- } \\
\text { Dudhala }\end{array}$ & 150 & $20-25$ & $2-3$ & $\begin{array}{l}\text { Cemented as well as Traditional houses } \\
\text { with Verandas were visited. }\end{array}$ \\
\hline 25 & Mukarpur & 50 & $5-10$ & NIL & $\begin{array}{l}\text { Cemented as well as Traditional houses } \\
\text { with Verandas were visited. }\end{array}$ \\
\hline 26 & Kolapur & 50 & $5-8$ & NIL & Only cemented Houses were visited. \\
\hline 27 & Bodla & 110 & $10-15$ & $2-3$ & Only cemented Houses were visited. \\
\hline 28 & Bairsal & 150 & $10-20$ & $2-3$ & Only cemented Houses were visited. \\
\hline
\end{tabular}


Present scenario in respect of House-Sparrows' depleting trends

\begin{tabular}{|l|l|l|l|l|l|}
\hline 29 & Bhadson & 200 & $20-30$ & $5-10$ & $\begin{array}{l}\text { Cemented as well as Traditional houses } \\
\text { with Verandas were visited. }\end{array}$ \\
\hline 30 & Barot & 100 & $10-20$ & NIL & Only cemented Houses were visited. \\
\hline 31 & Jainpur & 50 & NIL & NIL & Only cemented Houses were visited. \\
\hline 32 & Gadli & 100 & $10-20$ & NIL & Only cemented Houses were visited. \\
\hline 33 & Ban & 100 & NIL & NIL & Only cemented Houses were visited. \\
\hline 34 & Hinori & 100 & $10-20$ & NIL & Only cemented Houses were visited. \\
\hline 35 & Gudha & 100 & $10-20$ & $5-10$ & Only traditional Houses were visited \\
\hline 36 & Budha & 50 & NIL & NIL & Only cemented Houses were visited. \\
\hline 37 & Labkari & 100 & $10-20$ & NIL & Only cemented Houses were visited. \\
\hline 38 & Gari-birbal & 100 & $15-20$ & NIL & Only cemented Houses were visited. \\
\hline 39 & Pujam & 100 & NIL & NIL & Only cemented Houses were visited. \\
\hline 40 & Sirsala & 100 & $10-20$ & $2-3$ & Only traditional Houses were visited \\
\hline 41 & $\begin{array}{l}\text { Shadipur } \\
\text { Sahidan }\end{array}$ & 50 & NIL & NIL & Only traditional Houses were visited. \\
\hline 42 & Kirmich & 100 & $10-20$ & $2-3$ & Only traditional Houses were visited. \\
\hline 43 & Sonti & 50 & NIL & NIL & Only traditional Houses were visited. \\
\hline 44 & Haripur & 50 & NIL & NIL & Only traditional Houses were visited \\
\hline 45 & Kharindwa & 150 & $10-20$ & $2-3$ & Only traditional Houses were visited. \\
\hline 46 & Khairi & 100 & $20-30$ & $5-10$ & Only traditional Houses were visited. \\
\hline 47 & Rampur & 50 & $10-20$ & $2-3$ & Only traditional Houses were visited \\
\hline 48 & Berthala & 100 & $10-20$ & $2-3$ & Only traditional Houses were visited. \\
\hline 49 & Lohara & 100 & NIL & NIL & Only cemented Houses were visited. \\
\hline 50 & Nivarsi & 100 & $10-20$ & $2-3$ & Only traditional Houses were visited. \\
\hline
\end{tabular}

consists of insects (beetles, caterpillars, flies, and having mud-roof and Verandas with ventilator are aphids), arthropods, molluscs, crustaceans, present. Rajashekar and Venkatesha (2008) earthworms and sometimes even vertebrates such reported that House Sparrows habitually build nests as frog and lizards. It is crucial to mention that in tiled houses under the rafters and in holes in the house sparrow was found in pairs. Present studies roof of houses. The main cause of house sparrow also reveal that male and female perform all decline is lack of weed seeds, intensification of activities together like feeding, searching nest agriculture practices, and rapid use of insecticides materials, chirping. The present research endeavour (Girish et al., 2012; Grimmet, 1998). House also indicate that the population of House Sparrows sparrows generally built their nests in the crevices is higher in rural villages where there is availability of seeds, grains, insects, availability of nesting sites which support a good population of House Sparrow. McGillivray (1980) also observed higher population of House sparrows in rural Haryana. The present studies hint towards the fact that the possible cause of decline of population density of House sparrows in various villages in Kurukshetra district is due to construction of cemented House, absence of "Verandas", non-availability of Beri trees in the vicinity of houses, network of cable wires in and around houses, frequent use of insecticides which ultimately reduces the food availability. Population of House sparrows is much higher in those places where traditional old houses of thatched roofs of old houses, electric pipelines, in ventilation holes and space available on the electricity meters (Khera et al., 2010). Electromagnetic radiation from towers may be one of the factors for the decline of house sparrow population in rural and urban areas.

But due to urbanization and modernization in rural India especially in Haryana, villages are constructing cemented houses in place of traditional houses along with Verandas. In the city areas, sparrows in small groups were usually found resting on electric wires, nesting hanging from the tube lights and pipe lines that accidentally broken in the houses [Figs.7, 8, Plate-1]. It is pertinent to mention that in these cemented houses, house 
sparrow forms their nest in the ceiling of fan and other sockets for ornamental bulbs due to highly adapted nature [Figs.7, 8, Plate-1]. In these unusual nest lodging sites, there is risk of rolling down of nests on the ground to experience breakage (Summer, 2009; Tiwari , 1930). It is a big hurdle in the perpetuation of house sparrow population. The constant observations in houses of cities in particular reveal the absence of "Verandas" and hence non-availability of nesting place for House Sparrows. Persistent observations hint towards the fact that "BERI" trees are just absent in fore-court and rear-courts of houses and hence total elimination of roosting sites of house sparrows. These dual factors of absence of "Verandas" and elimination of "BERI" trees from house premises have dealt a severe blow to house sparrows' very existence. In these circumstances the following is conjectured: In the first place, the so called "Verandas" with "Jali-daar" cement sand "Jharokhas" on the outer periphery of "Verandas" can yield very effective results connected with assured hatching of the broods. Fortunately, House Sparrow experiences repeatedly broods. Hence, the office of Town-Planers must modify the approval standards of house building plans so us to incorporate "Verandas" in the fore courts and rearcourts of all houses including the very modern glass houses in one or the other way (Tyabji, 1992). Secondly, the Panchayats must importantly induce villagers to grow Beri trees in the possible places in the environs of the village surroundings. BERI plant is a very meaningful device of providing ROOSTING SITES in the non-breeding period for house sparrows. Thirdly, bushes be not cleared away in the name of cleansing the environment and surroundings on the pavements, outskirts of villages and towns. Instead, these bushes be substantiated by bushy and ornamental bushes like BOUGAINVILLEA etc.

Fourthly, in the modern perspective decorative "VINES" be moderated by trimming to assume BUSH-LIKE structure, at the altar of first floor in the façade portion of modern houses. Such structures are quite helpful in service of house sparrows, successful breeding. These measures, it is argued, be made mandatory, by law to restore house sparrow's alarming depleting populations in modern times. The organizers of national seminar, on enquiry were found in a state of inertia in respect of investment of efforts for the rehabilitation of House Sparrows. All educational institutions were found dis-interested in matters related with depletion of populations of House sparrows. National seminar organizers on Biodiversity conservation were found discussing worthless work toxicity by forcing cruelty on laboratory animals. All houses in villages, towns, cities were found with not sparrow nests. Hedges were trimmed so frequently leaving no chance for sparrows to chirp in the evening hours. All this indicate that no-body is engaged in efforts related with house sparrow rehabilitation (Yahya, 2001).

\section{Acknowledgements}

Authors are thankful to authorities of Kurukshetra University including Chairman, Department of Zoology for his cooperation.

\section{References}

Ali, S. and Ripley, S. D., 1987. Compact Handbook of the Birds of India and Pakistan (Second Edition): Oxford University Press, Delhi.

Ali, S. 1996. The Book of Indian Birds. $12^{\text {th }}$ Edition (Revised and enlarged). Oxford University Press, Mumbai.

Bhattacharya, R. Roy, R. and Goswami, C. 2011. Studies on the response of House Sparrow to artificial nest. International Journal of Environmental Science, 1(7):1574-1581.

Bhattacharya, R., Roy, R., Ghosh, S. and Dey, A. 2010. "Observations on house sparrow at Bandel, Hoogly", Proceedings of National Seminar on Biodiversity, Water resource and Climate change issues, March 10, 2010, Department of Environmental Science, Kalyani University, $147 \quad-152$.

Brooke, R. K. 1973. House Sparrows feeding in night in New York. The Auk. 90(1):206.

Daniels, R. J. R. 2008 "Can we save the sparrow? ' Current Science, 95 (11): 1527-1528.

Felemban, H. M. 1997. Morphological differences among populations of House sparrow from different altitude in Saudi Arabia. The Wilson Bulletin, 109(3):539-544.

Ghosh, S. Kim Ki Hyun and Bhattacharya, R. 2010. A survey on House Sparrow Population decline at Bandel, West Bengal, India. Journal of Korean Earth Science Society, 31(5): 448-453.

Girish, C., Ajay, K. and Parmesh, K. 2012. Population of House sparrow, Passer domesticus in different habitats of 
District Kurukshetra, Haryana. Journal of applied and Natural science, 10(1): 113-122.

Grimmet, R., Inskipp, C. and Inskipp, T. 1998. Birds of the Indian subcontinent. Oxford University Press, Delhi: 888.

Khera, N., Das, A., Srivastava, S. and Jain, S. 2010. "Habitat wise distribution of the House Sparrow (Passer domesticus) in Delhi, India"' Urban Ecosystem, 13(1):147154.

McGillivray, W B. 1980.Communal Nesting in the House Sparrow. Journal of Field Ornithology, 51 (4): 371-372.

Rajashekar, S. and Venkatesha, M. G. 2008. Occurrence of house sparrow Passer domesticus indicus in and around Bangalore. Current Science, 94(4):446 449.
Summers-Smith, J. D. 2009. "Family Passeridae (Old World Sparrows)". In del Hoyo, Josep; Elliott, Andrew; Christie, David. Handbook of the Birds of the World. Volume 14: Bush-shrikes to Old World Sparrows. Barcelona: Lynx Edicions.

Tiwari, N. K. 1930. An albino House Sparrow (Passer domesticus). J. Bombay Nat. Hist. Soc., 34(1): 253.

Tyabji, H. N. 1992. Flies forming a possible food supply for young House Sparrows Passer domesticus (Linn.). J. Bombay Nat. Hist. Soc., 88: 289.

Whistler, H. 1928. Popular Handbook of Indian Birds. London. Gurney and Jackson.

Yahya, H. S. A. 2001. The House Sparrow's turn? Sanctuary Asia, 21(1): 85. 